\title{
Decreasing occurrence of bacterial STD after introduction of voluntary counseling and testing HIV-program in Eldoret and Naivasha in Kenya in 1999-2013
}

\author{
G. Mikolasova', J. Kafkova', I. Gagova², Z. Bacikova', P. Minarik', Z. Paukovova², J. \\ Mutuku Muli², A. Murgova, L. Tkacova', M. Jankechova', D. Kalatova', \\ A. Mamova', D. Kimuli, J. Brnova', N. Kulkova', L. Michalikova', V. Krcmery’', \\ N. Mwanzia Kimuli1,3
}

Original Articles

${ }^{1}$ St. Elisabeth University of Health and Social Sciences, PhD Program Bratislava, Slovakia

${ }^{2}$ St. Ladislav Batthyany-Strattmann Clinic, Eldoret, Kenya

${ }^{3}$ St. Philippe Neri School, Joska, Kenya

\section{Correspondence to:}

St. Elisabeth University of Health and Social Sciences, Bratislava, Slovakia Nám. 1. Mája č. 1, 81000 Bratislava, Slovakia

Submitted: 17.6.2016

Revised: 28.8 .2016

Accepted: 10.9.2016

\section{Reviewers:}

V. Kozon

Allgemeines Krankenhaus - Medizinischer Universitätscampus, Vienna, Austria

V. Namulanda

Catholic University of Eastern Africa, Nairobi, Kenya

\section{Keywords:}

STD, AIDS/HIV.

CSWHI 2016; 7(3): 45-46; DOI 10.22359/cswhi_7_3_12 @ 2016 Clinical Social Work and Health Intervention

\section{Abstract:}

Introduction: HIV with Tuberculosis represent "deadly" synergy and HIV with STD "suffering": Synergy in areas of SS Asia with higher AIDS/HIV prevalence.

Patients and Methods: The aim of this research was to assess the impact of the community based integrated health program focused on HIV/ AIDS and tuberculosis (TB) on the occurrence of bacterial STD in the rural community of North Eldoret as well as in the area of Lake Naivasha in Kenya.

Results: Both areas home HIV prevalence of around 6\%. A dramatic decrease of HIV was correlated with sustained decrease of bacterial STD's (mainly syphilis and gonorrhea).

Conclusion: An integrated program of HIV/TB (STD) should be supported in the community with higher HIV prevalence. 


\section{Introduction}

Incidence of bacterial sexually transmitted diseases (STD) correlates with HIV as well with Hepatitis B and C and introduction of an integrated community program usually impacts multiple diseases. The aim of this research was to assess the impact of a community based integrated health program focused on HIV/AIDS and tuberculosis (TB) on the occurrence of bacterial STD in a rural community in North Eldoret as well as in the area of Lake Naivasha in Kenya, both areas with HIV prevalence of around $6 \%$.

\section{Patients and Method}

Among all outpatient department (OPD) visits during last 15 years (1999-2013) in both clinics serving about 50,00 people per year, incidence of STD and HIV in infections cases was assessed and correlated. An HIV VCT program has been established in 2008 as a VCT Center next to the Clinic, with one VCT Counselor and one Trained Nurse. All the VCT/HIV Program and all OPD visits for STD were recorded monthly.

\section{Results}

Among 42,711 OPD visits in last 4 years, STD was diagnosed in 1,446 patients $(3.39 \%)$ and HIV in 462 patients (1.08\%). However, when the Clinic started its work in 1999 , HIV prevalence in males was $8.6 \%$ and in females $11.9 \%$. A dramatic decrease of HIV was correlated with sustained decrease of bacterial STD's (mainly syphilis and gonorrhea). While in 2009, 505 cases of bacterial STD and 110 new cases of HIV were detected, in 2010; 421 STD's were diagnosed; 176 in 2011; 201 in 2012; 148 in 2013; followed by a decrease of HIV from 110 in 2009 to 53 in 2013. Unfortunately, while the proportion of adults with HIV and STD was decreasing in 1999-2013 by more than 3-fold, pediatric
STD in children $<5$ years increased from $1 \%$ in 1999 to $3 \%$ and $6 \%$ in 2010 and in 2013, respectively.

\section{Conclusion}

The integrated HIV/STD community program led to a 3.3 fold decrease of STD and a 2.1 fold decrease of HIV prevalence in the rural community of Eldoret, after 15 years of the introduction of VCT. Moreover, the increasing prevalence of STD in children 5 years of age is of great concern. A combination and integration of HIV programs is one of the priorities of UN/WHO, mainly in Sub-Saharan Africa, Central and South-East Asia. A Kenyan example from 1999-2013 shows the efficacy of concentered and integrated preventive and therapeutic programs for adults by improving their adherence to treatment.

\section{References}

1. JANKECHOVA M: (2007) The function of nursing in prevention of Lung Tuberculosis Proceedings Trnava, Typi Tyrnaviensis, pp 355, ISBN 978-80-870-52-8

2. KHASNIS AA, Nettleman MD: (2005) Global Warming and Infectious Disease. Archives of Medical Research,: Volume 36, Issue 6, 689-696

3. MANZARDO C, Trevigno B, Gómez I, Prat J, Cabezos J et al: (2008) Communicable diseases in the immigrant population attended to in a tropical medicine unit: Epidemiological aspects and public health issue. Travel Medicine and Infectious Disease, Vol. 6, Issue 1, Pages 4-11

4. WICZMANDYOVA, D, TKACOVA, L, MURGOVA, M: (2012) Proceedings Slov. Med. Univ.: The Socio Economic aspect of Migrations ISBN 978-80-89352-47-0, pp 62-70

5. WICZMANDYOVA D, MURGOVA A., The life of diabetics, life with diabetes Book.Clear Michalovce ISBN 978-809711629255.2012, pp 67 